\title{
Students' Understanding and Learning: Mediation Effects of Cognitive Engagement in Online Classes
}

\author{
Dr. C.Nagadeepa \\ Assistant Professor \\ Kristu Jayanti College, Bangalore \\ Dr. Reenu Mohan \\ Assistant Professor \\ Kristu Jayanti College, Bangalore \\ Dr. Raji S \\ Assistant Professor \\ Kristu Jayanti College, Bangalore \\ Dr. RAJA KAMAL CH \\ Assistant Professor, Department of Commerce \\ Kristu Jayanti College, Bangalore
}

Article History: Received: 10 November 2020; Revised 12 January 2021 Accepted: 27 January 2021; Published online: 5 April 2021

\begin{abstract}
:
Beneath the perils of pandemic, this trend has moved very fast and in a professional manner to fill in the space produced as a result of suspended classroom learning. During this pandemic the educational institutions have been forced to adopt online learning without practicing it. As a consequence, there are several challenges to be encountered by the facilitator as well as learners to benefit from it. This paper is a descriptive study of e learning scenario among the learners of higher education in commerce deanery. This paper aims at finding out the factors which lead to student's active engagement in the online classes. 1065 students from various colleges who had attended online classes in the last six months responded through a structured questionnaire and the data was analyzed to find out the students' understanding and learning.
\end{abstract}

Keywords: Online learning, Cognitive engagement, Institutional and Non Institutional support component, Social Component.

\section{INTRODUCTION}

Online-learning has been considered as a radical transformation in the years to come as a consequence of growth in the online education market and its quantitative outcome to boost employment opportunities, filling up the demand-supply gap in employment scenario of Indian companies. Online-learning has been observed as a campaigner amidst this chaos. It is assumed that the online platform for learning can be easily accessible as it can be made 
available to both urban and rural areas. It is thought out to be relatively cheaper as it brings down the cost of accommodation,transportation and the reduction in overall cost of institutionbased learning. Velocity MR, a market Research and Analysis company claims that 72 per cent of Indians choose online-learning over traditional classroom training. Indian students have hit upon online learning as a more ideal method of learning since most of the learners come from rural or semi-rural areas where the educational amenities, is below par. Online learning has become the next inclination in education worldwide because it provides access to educational opportunities in a flexible manner to students from diverse backgrounds and geographical regions who often can't access higher education by other means (Roll, Russell, \&Gašević, 2018).

Student engagement can be defined as "A student's behavioural,emotional and cognitive connection to their study" which has a direct impact on student success and achievement (Kahu, Stephens, Zepke, \& Leach, 2014, p. 523).

E-learning is considered beneficial for learners who are not so self-sufficient. A sudden shift to online learning with very little preparation and insufficient bandwidth may lead to a poor user experience. In a traditional classroom the teacher can move around, ask questions to students and clarify their doubts immediately by observing their body language and gestures. The students initially were not able to focus on these online platforms. Those who accepted the new learning environment with an open mind were able to adjust very soon. Learners who are shy in raising or speaking up their doubts in a traditional classroom often sense more confidence to do so when they are assured that they can't be seen by others during the class.

Similarly, the learners having physical disability who used to limit their participation in traditional classrooms are at no disadvantage in a virtual classroom wherein all the students are treated equal. There are a lot of interlinked factors which affects learner's experience and retention like study and family; ability to balance work, motivation, time management skills, sense of belonging, self-desire, course design and support systems. (Holder, 2007; Theodorou\&Pavlakis, 2008, Blackmon \& Major, 2012; Brown et al., 2015; Buck, 2016). Therefore, it is very important that proper quality check be done for enhancing the online learning.

Many students believe that as a result of e-learning, a new hybrid model of education will emerge, with significant benefits. The participation by students is not enough, educators must also put considerable effort to enhance the engagement of students, their attention in the class, assess the knowledge of learners and take feedbacks very often. Only then it will result in an effective and meaningful learning environment.

\section{LITERATURE REVIEW}

E-learning is becoming committed towards the development, advancement, flawlessness, refinement and viable routine with reference to long-lasting learning. The respondents acknowledged the reason as honing e-learning exercises, reinforce the long-lasting learning among numerous various networks over the globe (Harande\&Ladan, 2013). Experts of the field are of the opinion that new technologies should not be imposed without understanding these fundamental shifts among lecturers and students to (Odero, 2017).

Online learning can be considered as a tool which can make the teaching-learning process more innovative, more student-centered, and more flexible. Online learning is defined as "learning experiences in synchronous or asynchronous environments using different devices (e.g., mobile phones, laptops, etc.) with internet access. In these environments, students can be anywhere (independent) to learn and interact with instructors and other students" (Singh \& Thurman, 2019). 
The faculties need to spend a lot of time and efforts in making effective strategies for giving online instructions. Effective online instructions will help in getting feedback from learners, make learners ask questions, and broaden the learner's horizon for the course (Keeton, 2004). The educational institutions should focus on pedagogical issues and emphasize over case learning, collaborative learning and project-based learning through effective online instructions (Kim \& Bonk, 2006).

The schools and colleges need to be resilient When disasters and crisis occur, and should look out for new ways to continue the teaching-learning activities (Chang-Richards et al., 2013). Instruction, content, motivation, relationships, and mental health are the five important things that an educator must keep in mind while imparting online education (Martin, 2020).

\section{RESEARCH METHODOLOGY}

This is a descriptive study which aims to comprehend the significance of online learning during pandemic situations such as the Covid-19. The challenges concerned with classroom engagement of students during E-learning and the various factors affecting it were also identified. The primary objective of this study is to find out the mediating effect of students cognitive engagement between online teaching components and Learning achievement. Online learning was measured using Institutional Support components(IT) such as Teaching Presence component (TC) and Facility Component (FC), Non-institutional components (NIT) such as Social components (SC). In this the final outcome of online learning was measured with Understanding and Learning.

\subsection{Sample}

Undergraduate students from various colleges participated in the current research to test the proposed model at Bangalore City. Total of 1065 students took part in the survey. Simple random sampling method was used to collect the data. In this research the respondents are students from Undergraduate program consisting of 3 years (6 semesters) science, arts and management streams.

\subsection{Objective of the study:}

- To find out the significant impact of online teaching on students understanding and learning process.

- To find out the impact of student's cognitive engagement on their understanding and learning during their online classes.

- To evaluate the mediation effect of student's cognitive engagement on their understanding and learning during their online class.

Based on the objective the following hypothesis were developed.

H1: There is a significant influence of online teaching (TC,FC\& SC) on the student's understanding and learning.

$\mathrm{H} 2$ : There is a significant influence of student's cognitive engagement on the student's understanding and learning during online class

H3: Cognitive engagement of the students mediates the relationship between online teaching and student's understanding and learning 


\subsection{Theoretical Definitions:}

a) Institutional Support: This includes the support extended from educational institutions in promoting learning among students. It involves the quality of teaching, the software, moodles, apps, learning management system developed by the institutions to make learning comfortable for their students.

b) Non institutional support: This refers to the ambience and amenities made available at home by family in terms of money, internet, technical devices required for learning purposes.

c) Cognitive engagement: This includes the effort and interest shown by the students themselves to learn on their own and reinforce their knowledge, preparing their own notes

\subsection{Measures:}

A Five-point Likert scale was used to measure the research constructs. From the CoI survey instrument developed by Arbugh et al (2008) the teaching and social measures were adapted for this study. The modified instruments consist of 14 items for teaching presence divided into 7 items of institutional\& facility presence and further 7 items of social presence components. The cognitive engagement scale consists of 5 items and 7 items of Understanding and Learning adapted from Sarah Golden et.al. (2006). All the responses were measured with 5 point Likert scale ranged from strongly disagree $=1$ to strongly agree $=5$.

\section{DATA ANALYSIS AND INTERPRETATION:}

All the responses were coded and analyzed. The demography information such as gender $(42 \%$ are Male and 58\% are female), no of hours actively engaged in online classes at a stretch (less than 30 mins $=30 \%$, one hour $=50 \%$ and more than an hour is $20 \%)$, online class platform $(65 \%$ of them are learning through zoom, $20 \%$ of them are google meet and $15 \%$ of them are from other apps) and issues related to online classes (42\% of them are having unstable internet connectivity, $28 \%$ of the are having device problem, $19 \%$ of them are having social distractions and $11 \%$ of them are having other issues) were considered. The data were analysed in SPSS and AMOS23 (SEM) to examine the degree of goodness of fit and measured the mediation effect of cognitive enjoyment of students in online classes. The reliability of the measurement was carried out using CFA loading and construct composite reliability and both were falling under the minimum benchmark value of 0.70 and 0.80 . The following figure 1 explains the research problem and the mediating effect. 


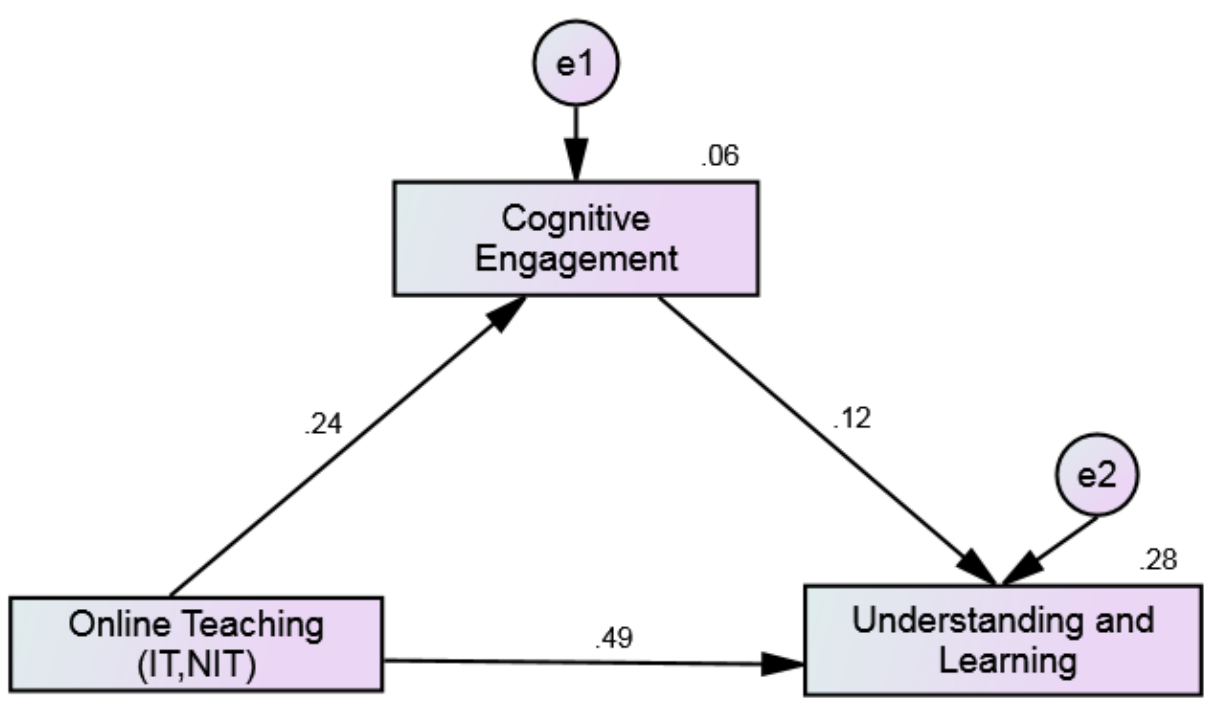

Figure 1: Mediation Effect of student's Cognitive Engagement during Online Class

The above figure 1 shows the structural equation model of the relationship between online teaching and attentive learning of the students via online classes and also the mediating role of cognitive engagement of the students during their online classes. The online teaching consists of institutional and non-institutional teaching presence which are considered as independent variables. The independent variables were measured with 14 items such as clear subject content delivery by teachers, student teacher interaction, peer group interaction, technical support from institution etc. Cognitive engagement which is considered as moderating variable was measured with 5 items such as engaging in discussion, self-initiated information seeking, submitting work on time, questions beyond the lecture/material provided etc. Finally the Understanding and Learning of the students which is dependent variable was measured with 7 items which support the students' learning and can develop their understanding in the online class room to reinforce their knowledge and working collaboratively in online class with items such as engaging themselves with the subject after online class, submission of the assignments on time, working independently as well as collaboratively with their peers in the classroom, reinforce their knowledge through online classes etc. The above model path figure outs the mediating effects of cognitive engagement of the students during their online classes.

The goodness fit of the study model is shown in the Table 1.The determinants of goodness fit indices are above the recommended yardstick which shows that the model constructs are fit as per the standards.

Table 1. Model Goodness Fit Indices

\begin{tabular}{|c|c|c|}
\hline Model & Parameters Recommended & Goodness of Fit \\
\hline X2/DF & $<3.0$ & 2.294 \\
\hline P-value & $<0.05$ & 0.000 \\
\hline IFI & $>0.9$ & 0.972 \\
\hline NFI & $>0.9$ & 0.933 \\
\hline CFI & $>0.9$ & 0.934 \\
\hline GFI & $>0.8$ & 0.946 \\
\hline AGFI & $>0.8$ & 0.878 \\
\hline
\end{tabular}




\section{RMSEA}

$<0.08$

0.063

The following table shows the standardized and unstandardized estimates, which represents the relationship among variables and significance between observed variables.

Table 2. Regression Weights

\begin{tabular}{|c|c|c|c|c|c|c|c|}
\hline & & $\begin{array}{c}\text { Standardized } \\
\text { Estimate }\end{array}$ & $\begin{array}{c}\text { Unstandardized } \\
\text { Estimate }\end{array}$ & S.E. & C.R. & P \\
\hline $\begin{array}{c}\text { Engagement } \\
\text { (CE) }\end{array}$ & $<---$ & $\begin{array}{c}\text { Online } \\
\text { Class } \\
\text { Teaching } \\
\text { (OT) }\end{array}$ & 0.244 & 0.316 & 0.039 & 8.037 & 0.000 \\
\hline $\begin{array}{c}\text { Understanding } \\
\text { and Learning } \\
\text { (AL) }\end{array}$ & $<---$ & $\begin{array}{c}\text { Cognitive } \\
\text { Engagement } \\
\text { (CE) }\end{array}$ & 0.116 & 0.144 & 0.034 & 4.227 & 0.000 \\
\hline $\begin{array}{c}\text { Understanding } \\
\text { and Learning } \\
(\text { AL) }\end{array}$ & $<---$ & $\begin{array}{c}\text { Online } \\
\text { Class } \\
\text { Teaching } \\
\text { (OT) }\end{array}$ & 0.492 & 0.789 & 0.044 & 17.967 & 0.000 \\
\hline
\end{tabular}

The above table reveals the relationship between the dependent and independent variables. As per the hypotheses, online class teaching has a significant influence on students understanding and learning even though they are in COVID stress and isolating situation with $p$ value less than 0.05 . Further, student's cognitive engagement also having significant influence on their understanding and learning. The proposed path coefficient online teaching and cognitive engagement $(\mathrm{OT} \rightarrow \mathrm{CE})$ for standardized and un-standardized estimates accounted for 0.244 and 0.316 respectively. With respect to cognitive learning and Understanding and Learning $(\mathrm{CE} \rightarrow \mathrm{AL})$ standardized estimates are 0.116 and un-standardized are 0.144 . Further, standardized estimates and un- standardized estimates of the path online teaching to Understanding and Learning of the students are accounted to 0.492 and 0.789 . hence the hypothesis $\mathrm{H} 1$ and $\mathrm{H} 2$ accepted and the null hypothesis rejected.

Further the mediating role of cognitive engagement of the students was tested with the help of the table 1 . The cognitive engagement was considered as the mediating variable, the structural path was not much improved. The direct effect of Online teaching on Understanding and Learning was high (standardized and un-standardized estimates are 0.492 and 0.789 ), but after the mediating variable was included it is less than the direct effect. Hence, cognitive engagement of the students is not mediating the Understanding and Learning of the students and $\mathrm{H} 3$ is rejected and null hypothesis is accepted.

\section{SUMMARY OF FINDING \& CONCLUSION}

\subsection{FINDINGS}

The findings revealed that online teaching presence such as subject content delivery by teachers, student teacher interaction, pear group interaction, technical support from institution are having significant influence on students Understanding and Learning $(\beta=0.492, \mathrm{R} 2=$ 0.286 and $\mathrm{p}$-value of $0.000<0.01$ at $1 \%$ level of significance). These findings regarding student teacher interaction has been reiterated by Liu (2016) and Nguyen (2017). And also pear group discussion/interaction via forum discussion, chat messages, group assessment etc., was reiterated by GrantS (2016) and Tabouris et al (2014). The mediation of cognitive 
engagement of the students are not supported in this study is not in line with the study of Ahmed Siddiqi (2018).

\subsection{CONCLUSION}

The research concludes that the students understanding and learning in online classroom is influenced the most by their cognitive engagement and less influence by the institutional or non-institutional support system. The willingness to listen, concentrate and participate in the classroom must arise from the students. The responsible behaviour among the higher learning students makes the learning interesting and involving. Nevertheless, the effectiveness of online learning varies across the age groups. The students who do not have access to all online technology need not be neglected. These students are less affluent and belong to less techsavvy families with financial resources restrictions. Proper planning ought to be done so that they may not lose out when classes occur online. They may be affected by the heavy costs associated with digital devices and internet data plans.

\subsection{LIMITATIONS AND SCOPE FOR FURTHER STUDIES}

The present study was conducted to examine online teaching and Understanding and Learning of the students and the mediating effect of cognitive engagement of students of Bangalore city. The study covered only few institutional and non-institutional teaching presence of online learning. The future studies may widen the study scope to other geographical areas like rural areas. And they can also further extend the mediating variable such as behavioral engagement, emotional engagement etc. The study is based on quantitative data, further study may consider mixed method both qualitative and quantitative.

\section{REFERENCES:}

1) Ahmed Siddiqi (2018). Mediating role of student's engagement to their classes: An Experience from higher education in Pakistan, Asian Association of Open Universities Journal, Vol 13 issue 2.

2) Allen, J.M., Wright, S., Cranston, N., Watson, J., Beswick, K. and Hay, I. (2018), "Raising levels of school student engagement and retention in rural, regional and disadvantaged areas: is it a lost cause?", International Journal of Inclusive Education, Vol. 22 No. 4, pp. 409-425.

3) Chang-Richards, A., Vargo, J., Seville, E. (2013). Organisational resilience to natural disasters: New Zealand's experience (English translation). China Policy Review, 10, 117-119.

4) Blackmon, S. J., \& Major, C. (2012). Student experiences in online courses: A qualitative research synthesis. Quarterly Review of Distance Education, 13(2), 77-85.

5) Brown, M., Hughes, H., Keppell, M., Hard, N., \& Smith, L. (2015). Stories from students in their first semester of distance Learning. The International Review of Research in Open and Distance Learning, 16(4), 1-17.

6) Buck, S. (2016). In their own voices: Study habits of distance education students. Journal of Library \& Information Services in Distance Learning, 10(3-4), 137-173. https://doi.org/10.1080/1533290X.2016.1206781.

7) Darling-Hammond, L., Flook, L., Cook-Harvey, C., Barron, B. \&Osher, D. (2020). Implications for educational practice of the science of learning and development. Applied Developmental Science, 1-44. DOI: 10.1080/10888691.2018.1537791

8) Delaney, L., \& Brown, M. (2018). To walk invisible: Distance students in a dual mode university. Distance Education, 39(2), 209-223.

9) Ghavifekr, S. \&Rosdy, W.A.W. (2015). Teaching and learning with technology: Effectiveness of ICT integration in schools. International Journal of Research in Education and Science (IJRES), 1(2), 175- 191.

10) Holder, B. (2007). An investigation of hope, academics, environment, and motivation as predictors of persistence in higher education online programs. The Internet and Higher Education, 10(4), 245-260. https://doi.org/10.1016/j.iheduc.2007.08.002. 
11) Humphries, S. (2010). Five challenges for new online teachers. Journal of Technology Integration, 2, 15-24.

12) Kahu, E. R. (2013). Framing student engagement in higher education. Studies in Higher Education, 38(5), 758-773. https://doi.org/10.1080/03075079.2011.598505.

13) Keeton, M. T. (2004). Best online instructional practices: Report of phase I of an ongoing study. Journal of Asynchronous Learning Networks, 8(2), 75-100.

14) Kim, K.-J., Bonk, C. J. (2006). The future of online teaching and learning in higher education: The survey says. Edu cause Quarterly, 4, 22-30.

15) Limperos, A. M., Buckner, M. M., Kaufmann, R. \&Frisby, B. N. (2015). Online teaching and technological affordances: An experimental investigation into the impact of modality and clarity on perceived and actual learning.

16) Martin, A. (2020). How to optimize online learning in the age of coronavirus (COVID-19): A 5-point guide for educators.

https://www.researchgate.net/publication/339944395_How_to_Optimize_Online_Learning_i n_the_Age_of_Coronavirus_COVID-19_A_5-Point_Guide_for_Educators

17) Harande, Y.I. and Ladan, B.F. (2013) Scholarly communication trends through the Literature of mathematics education. International Journal of Humanities and Social Science, 3: 16, 1-8

18) Odero, J. (2017). ICT-based distance education, a study of university students' views and experiences in early post-apartheid South Africa. Phd Dissertation International and Comparative Education at Stockholm University. Institution for pedagogic.

19) Sarah Golden, Tami McCrone, Matthew Walker and Peter Rudd(2006). Impact of e-learning in Further Education: Survey of Scale and Breadth. National Foundation for Education Research Report 745.

20) ShivangiDhawan (2020), Online Learning: A Panacea in the Time of COVID-19 Crisis,Journal of Educational Technology systems, Vol. 49(1) 5-22

21) Singh, V. \& Thurman, A. (2019). How many ways can we define online learning? A systematic literature review of definitions of online learning (1988-2018). American Journal of Distance Education, (33)4, 289- 306. https://doi.org/10.1080/08923647.2019.1663082.

22) Tambouris, E., Zotou, M., \&Tarabanis, K. (2014). Towards designing cognitively-enriched project-oriented courses within a blended problem-based learning context. Education and Information Technologies, 19(1), 61-86. http://doi.org/10.1007/s10639-012-9209-9

23) Viet Anh Nguyen (2017). The impact of online learning activities on student learning outcome in blended learning course. Journal of Information \& Knowledge Management (JIKM), https://doi.org/10.1142/S021964921750040X. 